\title{
ТЕХНОЛОГИИ ЗОЛОТОЙ ОРДЫ: КИРПИЧ УКЕКА
}

\author{
(C) 2021 г. Р.А. Сингатулин
}

Статья посвящена исследованиям кирпичного строительного материала из Увекского городища (г. Саратов) по данным полевых и камеральных исследований 1994-2020 гг. Целью исследований являлось дефиниция физико-химических характеристик кирпича из строений Увекского городища для историко-архитектурного, технико-экономического обоснования строительных технологий Золотой Орды, проведения реконструкционных и реставрационных работ, компьютерного моделирования в системах виртуальной и дополненной реальности. В работе приводятся данные по разнообразию форм и размеров кирпича, отпечаткам на его поверхности. Рассматриваются результаты исследований по определению элементного состава керамического материала методами Оже и вторичной-ионной массспектроскопии (ВИМС) с целью идентификации мест добычи сырья. Приводятся данные по: средней плотности кирпича, его группе по теплотехническим характеристикам, коэффициенту излучения, водопоглощению по массе, пределам прочности при сжатии и изгибе, определению марки кирпича в соответствии с регламентируемыми параметрами действующего государственного стандарта.

Ключевые слова: археология, Укек, Золотая Орда, кирпич, форма, размеры, элементный состав, теплотехнические и прочностные характеристики.

\section{GOLDEN HORDE TECHNOLOGIES: BRICKS FROM UKEK}

\section{R.A. Singatulin}

The paper discusses a ceramic bricks from Uvek settlement using the results of field and laboratory studies of 1998-2020. The goal of the research was to define the physico-technical characteristics of bricks from Uvek settlement for historico-architectural, technical and economic substantiation of the construction technologies of the Golden Horde, for reconstruction and restoration work, for computer modeling in virtual and augmented reality systems. The paper presents data on the diverse shapes and dimensions of the bricks, and the imprints on its surface. It discusses the results of studies aimed at establishing the elemental composition of the ceramic material using the Auger method and secondary ion mass spectroscopy (SIMS) to identify the raw material mining sites. Data is provided on the average density of the brick, its group in terms of thermal characteristics, emissivity coefficient, water absorption by weight, ultimate compression and bending strength, and its brand in accordance with the parameters regulated by the state standard in effect.

Keywords: archaeology, Ukek, Golden Horde, brick, shape, dimensions, elemental composition, thermal and strength characteristics.

Введение. Изучение строительных технологий Золотой Орды, основанных на археологических источниках, в настоящее время приобретает особую актуальность (Зивилинская, 2016). Актуализация проблемы связывается с введением в научный оборот новых данных полевых исследований, широким использованием в камеральных исследованиях методов математической статистики, твердотельного 3D-моделирования, технологий промышленного анализа для строительных материалов и других современных методов и средств.

Средневековые города Поволжья, начиная с Волжской Булгарии, Золотой Орды и заканчивая Казанским и Астраханским ханствами, характеризовались высоким уровнем городского строительства (Фёдоров-Давыдов, 1994). Традиции, преемственность, импорт технологий и их новое развитие в условиях новообразованного государства связываются с формированием особого волжского технологического уклада, получившего определение в литературе как феномен Золотой Орды (Кульпин, 2001, с. 74-88). В этой связи особый интерес вызывают градостроительные технологии золотоордынского города Укека, который известен не только своим ранним упоминанием в записках миссионеров, купцов и путешественников, но и своей ролью в формировании золотоордынского технологичного уклада (рис. 1). Рассматривая производство кирпича как своеобразный индикатор уровня технологичности общества, есть основания полагать, что необходимый объём строительного материала для новостроек Укека заранее рассчитывался для каждого объекта с учётом его функционального назначения, геометрии, особенностей окружающего ландшафта, требований заказчика и других критериев. То 
есть «проектная документация» на возведение кирпичного сооружения в той или иной форме уже существовала. Например, чтобы возвести только один мавзолей, описанный А.А. Кротковым (Кротков, 1915, с. 111-113), с размерами основания $21,33 \times 12,54$ м при толщине стен от 1,6 до 2,3 м и высоте прямоугольной части здания до 5 м (без учёта купольной надстройки) с объёмом кирпичного заполнения в 417 куб. м потребовалось бы не менее 134000 штук обожжённого кирпича условного размера $25 \times 25 \times 5 \mathrm{~cm}$. На практике это означало, чтобы возвести мавзолей, нужно было создать непрерывную производственную цепочку, начиная от эскизного проекта, выбора места строительства, расчёта необходимого объёма строительного материала, подготовки строительной площадки, подбора квалифицированного персонала, наличия и подвоза необходимого сырья, инструмента, необходимости горна (печи) для обжига кирпича, заготовки дров и другой сопутствующей производственной инфраструктуры. Организация непрерывного производственного цикла при изготовлении строительного материала, а тем более само возведение кирпичных зданий, различных ирригационных и водопроводных сооружений на активных оползневых отложениях Увекской гряды (Дунаева, Рагозин, 1962), были под силу общественно-экономической формации, стоящей на достаточно высоком технологичном уровне. Золотая Орда таким технологическим уровнем обладала.

Материалы и методы исследования. Основным материалом для исследований служили данные археологических отчётов 2002-2016 гг. и геофизических исследований 1994-2002 гг. (Р.А. Сингатулин), материалы археологических раскопок 1891-1923 гг. (Отчёт..., 1891; Кротков, 1915; Баллод, 1923), использовались коллекции подъёмного материала (обожжённого кирпича) из фондов Саратовского областного и Энгельсского краеведческих музеев. Камеральные исследования 1999-2020 гг. проводились в испытательной лаборатории кафедры «Строительные материалы и технологии» Саратовского государственного технического университета (СГТУ) имени Ю.А. Гагарина (зав. лаб. Д.К. Тимохин) и лаборатории информационных технологий в гуманитарных и естественнонаучных исследованиях Саратовского госуниверситета (СГУ) имени Н.Г. Чернышевского (зав. лаб. Р.А. Сингатулин). В рамках традиционных общенаучных методов, таких как сбор и обработка статистической информа-

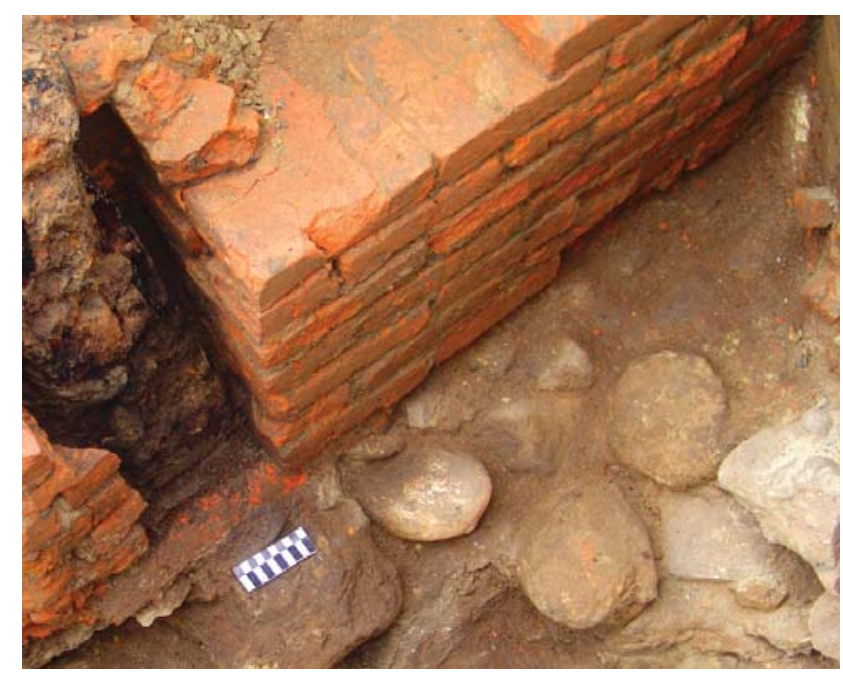

Рис. 1. Фрагмент стены здания Укека (Увекское городище, 2006 г.)

Fig. 1. Fragment of the wall of a building in Ukek (Uvek settlement, 2006)

ции (Фёдоров-Давыдов, 1987, с. 95-97; Васильев, 2004, с. 72-79), было обработано около 1650 фрагментов и 570 цельных форм. Измерение кирпича в слое (по видимой поверхности, без извлечения строительного материала из сооружения) осуществлялось в видимом и инфракрасном диапазонах шкалы электромагнитных волн с помощью стереофотограмметрической аппаратуры (Сингатулин, 2016а, с. 90-93), с применением методологии для цифровых неметрических камер и лазерных систем (Краснопевцев, 2008), программного обеспечения «Photomod» фирмы «Ракурс» (г. Москва). Часть исследуемого материала с целью дефиниции элементного состава с местами предполагаемой добычи сырья (глины) была обработана методами Оже-спектроскопии и вторичной ионной масс-спектроскопии (ВИМС) в проблемной лаборатории кафедры «Теоретической и математической физики» СГУ (зав. лаб. А.Г. Лавкин) (Сингатулин, 2016б, с. 105-107) и сертифицированной лаборатории ВПК (г. Заречный Пензенской области, В.А. Винничек).

Хронологические рамки исследований охватывают вторую половину XIII в. - начало XIV в. и по 1360-1361 гг. (Сингатулин, 2008, c. 145,153$)$.

Форма и размеры кирпича. Разнообразие форм и размеров обожжённого кирпича с Увекского городища представлены в таблице 1 (в таблицу не включён статистический материал по формам и размерам кирпича, полученный путём механического воздействия (обломом, распиливанием) из более крупных форм кирпича). Форма основного строительного 
материала варьировалась: использовались квадратные, половинчатые (прямоугольные), вогнуто-выпуклые, треугольные, полукруглые и фигурные в плане кирпичи.

Наиболее распространённым строительным стандартом золотоордынского Укека является кирпич квадратной формы из красножгущей глины. Среднестатистические размеры кирпича 234×228×52 мм (Сингатулин, 2017, c. 65-68). Нижний предел размеров кирпича данной группы составляет $221 \times 218 \times 46$ мм, верхний - $242 \times 251 \times 59$ мм. Линейный разброс параметров для сторон стандартной квадратной конфигурации кирпича составил
$21 \times 33 \times 13$ мм, или около $8 \%$ от среднестатистического размера. Для кирпича, датируемого второй половиной XIII в. - первой половиной XIV в. (Кротков, 1915 и др.), разброс геометрических параметров более значителен. Так, согласно данным фотограмметрической обработки стереоснимков раскопок на Увеке в 1913 г. (Сингатулин, 2014, с. 149-151), разброс линейных параметров кирпича (по площади видимой поверхности) из строений может достигать величины 12-15\% (и более) от размера $264 \times 220 \times 66$ мм, приведённого А.А. Кротковым (Кротков, 1915, с. 112). Грани кирпичей из этих строений имеют сглажен-

Таблища 1. Геометрические формы и среднестатистические размеры кирпича с Увекского городища

Table 1. Geometric Shapes and Average Dimensions of Bricks from Uvek Settlement

\begin{tabular}{|c|c|c|c|c|c|c|}
\hline $\begin{array}{l}\text { № } \\
\text { п/ } \\
\text { ח }\end{array}$ & $\begin{array}{c}\text { Геометриче } \\
\text { ская форма } \\
\text { кирпича }\end{array}$ & $\begin{array}{c}\text { Описание и } \\
\text { ориентировочна } \\
\text { я датировка }\end{array}$ & $\begin{array}{c}\text { Среднестатист } \\
\text { ические } \\
\text { размеры (длина } \\
\text { х ширина х } \\
\text { высота) в мм }\end{array}$ & $\begin{array}{c}\text { Средняя } \\
\text { плотность в } \\
\text { кг } / \mathrm{M}^{3}\end{array}$ & $\begin{array}{c}\text { Масса } \\
\text { кирпича в кг }\end{array}$ & $\begin{array}{c}\text { Процент } \\
\text { исследуемог } \\
\text { о кирпича к } \\
\text { общему } \\
\text { количеству в } \\
0,00 \% \\
\end{array}$ \\
\hline 1 & 2 & 3 & 4 & 5 & 6 & 7 \\
\hline 1 & & $\begin{array}{l}\text { Квадратная } \\
\text { форма темно- } \\
\text { красного цвета. } \\
\text { Вт. пол. XIII - } \\
\text { пер. пол. XIV в. }\end{array}$ & $\begin{array}{c}264 \times 220 \times 66 \\
\text { (размеры по } \\
\text { А.А. Кроткову) }\end{array}$ & - & - & 0,17 \\
\hline 2 & & $\begin{array}{l}\text { Квадратная } \\
\text { форма ярко } \\
\text { красного цвета. } \\
1360-1361 \text { гг. }\end{array}$ & $234 \times 228 \times 52$ & 1196 & 3,4 & 73,68 \\
\hline 3 & & $\begin{array}{l}\text { Квадратная } \\
\text { форма ярко } \\
\text { красного цвета, } \\
\text { на нижней } \\
\text { поверхности } \\
\text { продольные } \\
\text { выемки (рис. 2). } \\
1360-1361 \text { гг. }\end{array}$ & $\begin{array}{c}234 \times 228 \times 52, \\
\text { продольные } \\
\text { выемки } \\
\text { шириной } 20-25 \\
\text { мм, глубиной } \\
3-5 \text { мм }\end{array}$ & 1196 & 3,4 & 11,57 \\
\hline 4 & & $\begin{array}{l}\text { Квадратная } \\
\text { форма чёрного } \\
\text { цвета, прогнутая } \\
\text { в центральной } \\
\text { части. } \\
\text { Вт. пол. XIV в. }\end{array}$ & $\begin{array}{c}221 \times 226 \times 47, \\
40 \text { мм } \\
\text { максимальный } \\
\text { прогиб от } \\
\text { горизонтально } \\
\text { й линии } \\
\text { основания }\end{array}$ & $\sim 1300$ & $\sim 3$ & 0,52 \\
\hline 5 & Ease & $\begin{array}{l}\text { Половинчатая } \\
\text { форма ярко } \\
\text { красного цвета. } \\
1360-1361 \text { гг. }\end{array}$ & $224 \times 122 \times 49$ & 1196 & 1,6 & 11,4 \\
\hline 6 & & $\begin{array}{l}\text { Половинчатая } \\
\text { форма темно- } \\
\text { красного цвета. } \\
\text { Вт. пол. XIII - } \\
\text { пер. пол. XIV в. }\end{array}$ & $\begin{array}{l}264 \times 132 \times 66 \text { (из } \\
\text { фондов СОМК) }\end{array}$ & 1220 & 2,8 & 0,17 \\
\hline 7 & & $\begin{array}{l}\text { Прямоугольная } \\
\text { форма серого } \\
\text { цвета с } \\
\text { полированной } \\
\text { поверхностью. } \\
\text { XV-XVIII вв. }\end{array}$ & $235 \times 175 \times 55$ & 1318 & 3,0 & 0,17 \\
\hline
\end{tabular}




\begin{tabular}{|c|c|c|c|c|c|c|}
\hline 8 & & $\begin{array}{l}\text { Большой } \\
\text { прямоугольный } \\
\text { треугольник } \\
\text { ярко красного } \\
\text { цвета. } \\
1360-1361 \text { гг. }\end{array}$ & $\begin{array}{c}221 \times 222 \times 48, \\
\text { диагональ } \\
316 \text { мм }\end{array}$ & 1196 & - & 0,87 \\
\hline 9 & 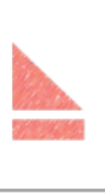 & $\begin{array}{l}\text { Малый } \\
\text { прямоугольный } \\
\text { треугольник } \\
\text { ярко красного } \\
\text { цвета. } \\
1360-1361 \text { гг. }\end{array}$ & $\begin{array}{c}120 \times 95 \times 44, \\
\text { диагональ } \\
151 \text { мм }\end{array}$ & 1196 & - & 0,87 \\
\hline 10 & & $\begin{array}{l}\text { Карнизная } \\
\text { полукруглая } \\
\text { форма с } \\
\text { фасонным } \\
\text { полукруглым } \\
\text { углублением } \\
\text { (рис. 3). } \\
1360-1361 \text { гг. }\end{array}$ & $\begin{array}{c}255 \times 121 \times 74, \\
\text { полукруглое } \\
\text { углубление } \\
\text { радиусом } 35 \\
\text { мм, диаметр по } \\
\text { дуге изгиба } \\
\text { около } 1,8 \text { м }\end{array}$ & 1196 & - & 0,52 \\
\hline
\end{tabular}

ные края, значительный разброс размеров по длине и высоте, что указывает на иную технологию ручной формовки, чем при использовании шаблонных форм.

Особый интерес вызывает кирпич с продольными выемками на нижней рабочей стороне (рис. 2). Впервые такой кирпич был зафиксирован при раскопках Л.Л. Галицына и С.С. Краснодубровского в 1891 г. (Отчёт..., 1891). Среднестатистический размер $234 \times 228 \times 52$ мм (табл. 1, № п/п 3). Профиль нижней поверхности сформирован с помощью пальцев рук. Глубина вдавливания около 3-5 мм, достигая в отдельных экземплярах величины 12-18 мм. Ширина выемок около 20-25 мм. Количество выемок на нижней поверхности плинфы колеблется от 8 до 10. Выемки сформированы обеими руками формовщика. Необходимость выемок связывается с обеспечением лучшего сцепления с раствором в кладке. Профильный кирпич прослеживался поверх фундаментной кладки
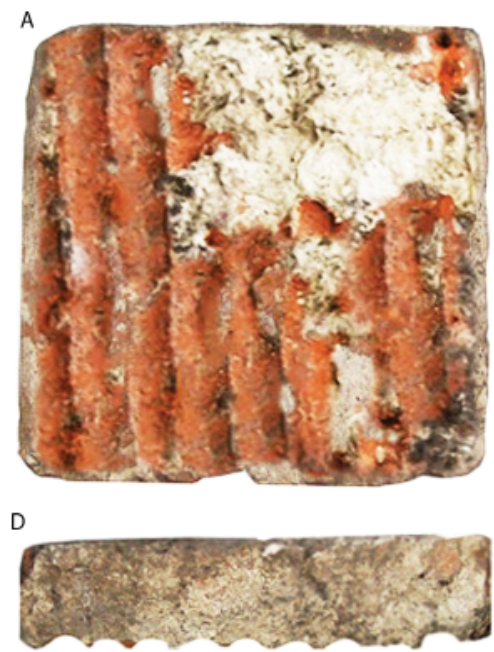
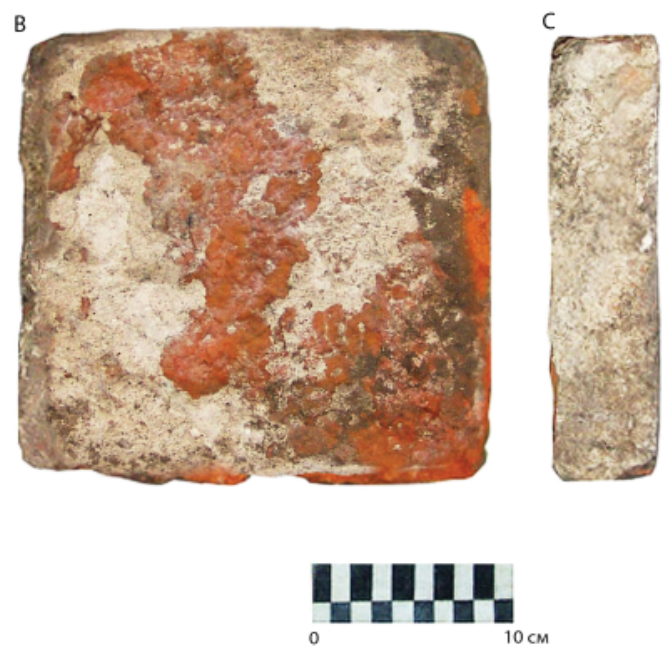

Рис. 2. Кирпич с нижними параллельными бороздками Fig. 2. Brick with bottom parallel channels

из валунов, залитых плотным известковым раствором, и частично наблюдался на втором и третьем ряду кирпичной кладки (Сингатулин, 2016в, с. 18, 50, 51).

Геометрические формы квадратного кирпича (табл. 1, № п/п 4) из красножгущей глины имеют характерную прогнутую основу, которая, возможно, образовалась при прогибе пластической массы во время сушки. Боковые поверхности кирпича строго параллельны. Усреднённые размеры кирпи- ча $221 \times 226 \times 47$ мм. Максимальный прогиб от условно проведённой горизонтальной линии основания - 40 мм. Было обнаружено несколько подобных экземпляров. Чрезвычайно твёрдый и прочный кирпич. Цвет поверхности чёрный со следами вплавленного стекла. На сколах цвет теста темно-красный. Кирпич не пережжён, но на поверхности прослеживаются следы от продолжительного воздействия высоких температур. Следов скрепляющего известкового раствора на поверхности не 
обнаружено. Предположительно, описываемый образец использовался в конструкции печи или дымохода.

Отдельного внимания заслуживает полукруглая кирпичная форма (рис. 3) (Синга-
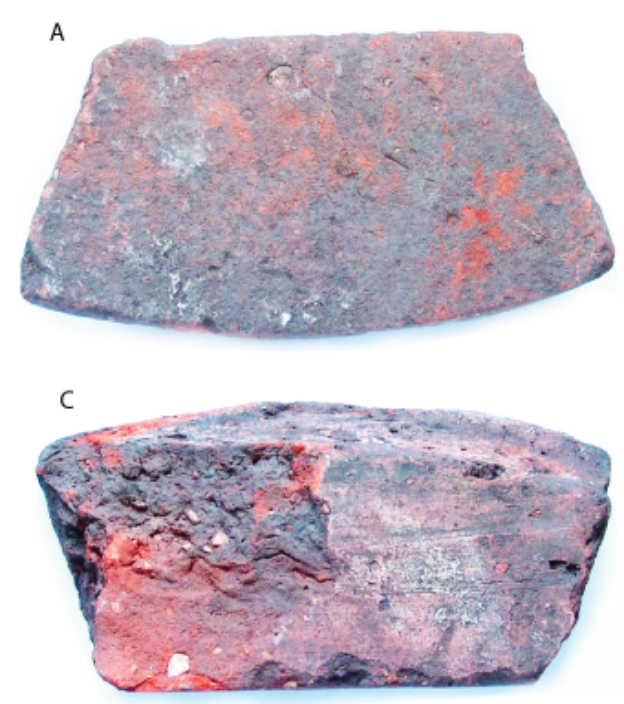

Рис. 3. Кирпич полукруглой формы

Fig. 3. Brick with a half-round shape
B
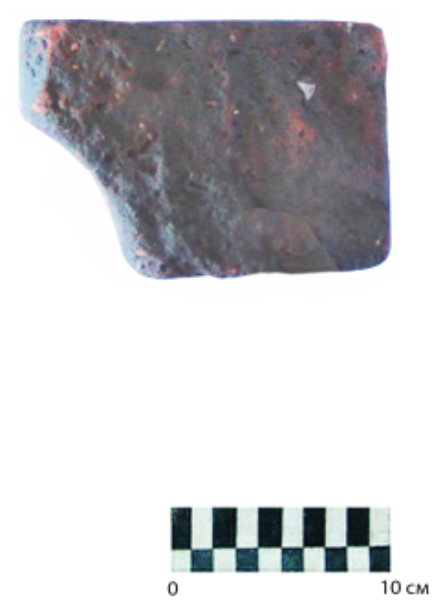

ней и нижней поверхности кирпича фиксируются следы тонкой известковой обмазки.

В процессе археологических исследований 2004 г. (Сингатулин, 2006, с. 82) к юго-востоку от «мамайского» бугра были отмечены половинчатые кирпичи $235 \times 175 \times 55$ мм (табл. 1 , № п/п 7) сероватого цвета с верхней отполированной поверхностью. Вероятно, кирпичи использовались в качестве напольного покрытия или ступенек порога. Внешний вид, размер и состав теста на сколах визуально отличается от типичного кирпича из красножгущей глины: тщательно выровненные поверхности, более аккуратные бортики, более мелкие (просеянные) включения. Анализ элементного состава показал высокое содержание силикатов. Идентифицировать состав с другими образцами или связать его происхождение с местными источниками сырья не удалось. Анализ разрушенного сооружения, его состояние, небрежный способ кладки кирпича разного размера, обмазка серого цвета поверх белой известковой и др. указывают на их вторичное использование в более позднее время, предположительно в XV-XVIII вв. (Браташова, 2016, c. 216-217).

Отпечатки на поверхности кирпича. Отпечатки клейм, знаки и надписи не так часто встречаются на золотоордынском кирпиче. Так, клейма были предназначены для обозначения прав собственника, но, вероятно, могли отражать и некоторую идеологию, ритуал или технологическую процедуру, предназначенную для маркировки ограниченной партии продукции. Например, партия строительного материала могла объединяться особым составом керамического теста, ограничиваться объёмом загруженного кирпича для обжига и другими обобщающими признаками. При этом достаточно было промаркировать один или несколько кирпичей из некоторой серии, объединённой «родственными» критериями.

Технологические отпечатки, которые образовались в процессе производства, носят иной характер. Они несут информацию о характере производственного процесса, степени его воздействия на предметы материальной культуры и другую важную источниковедческую информацию (Ёлшин, 2010, с. 398). К сожалению, в настоящее время отработать качественную методику обработки золотоордынского строительного материала из-за отсутствия доверительной базы данных не представляется возможным. Но необходимость такой специализированной базы данных, основанной на точной фиксации объекта исследований, его связей с пространственным окружением, алгоритмом раскопок, использованием геоинформационных технологий, очень востребована. Внимание к отдельным эпизодам, случайным процессам, совпадениям необходимо донести до информационно-логистического уровня, когда незначительные детали (маркеры) превращаются в значимые критерии, на осно- 
вании которых можно прийти к новым знаниям. Имеется немало случаев, когда в качестве условного маркера выступают случайные процессы, которые дают богатую пищу для различных интерпретаций. В первую очередь речь идёт о следах, оставленных человеком (гомеоскопия), животными, птицами, растениями, инструментами, строительным материалом (механоскопия) и др. В большинстве случаев отпечатки могли образоваться в период двухнедельной (10-14 дней) сушки кирпичных форм, причём в самый начальный её период (1-3 дня), когда поверхность изделий ещё достаточно пластична. В общей статистике исследований процент зафиксированных и интерпретированных отпечатков на поверхности строительного материала из Увекского городища составляет 54\%. Из них: гомеоскопические следы - 16\%, механогомия (следы одежды, обуви человека и т. п.) - 4\%, следы механоскопии - $12 \%$, следы животных и птиц $-6 \%$, и растений $-22 \%$.

Нередко на поверхности кирпичных форм наблюдаются групповые отпечатки (Сингатулин, 2008, с. 145). На рисунке 4 представлен фрагмент кирпича с отпечатками кошачьего следа (рис. 4cII), ромбовидной формы мозаичного декора (рис. 4cIII), а на противоположной стороне - следы стеблей травы и колоска её зерновки (рис. 4aI) (Сингатулин, 2008, c. 145). Трава была идентифицирована как «Пырей ползучий» (Elitrigia repens) - одно из самых распространённых многолетних травянистых растений. Ботаническое описание: плоские листья длиной от 12 до 40 см, шириной 3-10 мм. Произрастает преимущественно на лугах, травянистых склонах и др. Цветёт в июне-июле, плодоносит в июле-сентябре (Губанов и др., 1976, с. 54). Идентификация отпечатков растения и его плодов позволяет определить временные рамки технологической сушки кирпичных форм из-за ботанических особенностей времени плодоношения данной травы, что позволяет реконструировать некоторые технологические особенности средневекового производства. Технологический процесс сушки предполагает поэтапное переворачивание кирпичных форм, причём процедура их раскладывания на горизонтальной поверхности, по всей вероятности, осуществлялась на участках, на которых ранее осуществлялись другие работы (размещение и подгонка мозаичных форм для облицовки стен и др.). Дефицит открытых пространств из-за сильно пересечённого рельефа и плотной застройки для Укека вполне очевиден. Для производства кирпича, а тем более для технологической сушки использовались не только свободные горизонтальные участки, но и территории восточных травяных склонов Увекской гряды. Занимаемая площадь для формовки и технологической сушки была достаточно велика. Расчёты показывают, что при одновременном возведении 4 зданий, каждое ориентировочно размером не менее $20 \times 10 \times 5$ м с толщиной стен 0,75 м, при объёме кирпичного заполнения в 225 куб. м, потребуется не менее 326800 штук кирпича. При условной минимальной одноразовой загрузке в обжигательную печь партии из 2000 штук занимаемая площадь формовки и сушки составит не менее 1200 кв. м, а общая необходимая производственная площадь для 4 зданий охватит около 200000 кв. м! Разумеется, что площадь формовки и сушки могла быть существенно меньше за счёт оптимизации производственно-временной цепочки «сырьё - формовка - сушка - обжиг - склади-

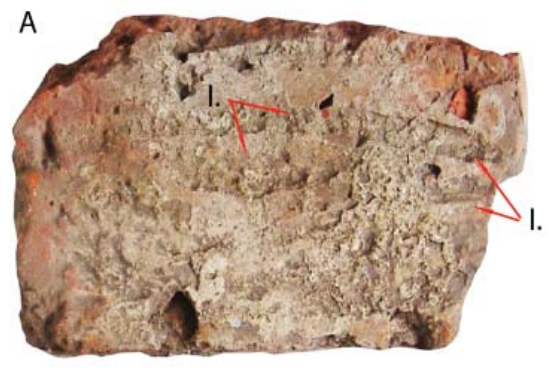

D

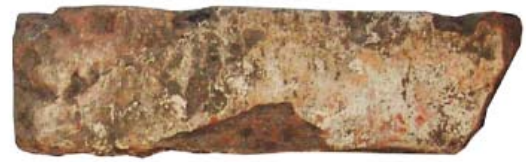

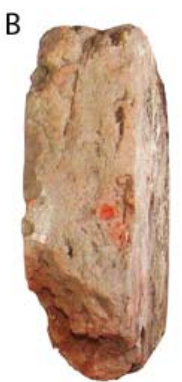

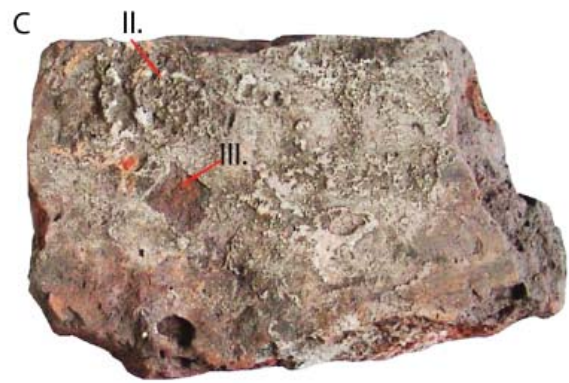

II.

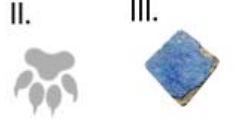

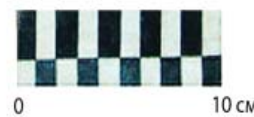

Рис. 4. Кирпич с отпечатками травы (I), следа кошки (II), мозаики (III)

Fig. 4. Brick with imprints of grass (I), cat's footstep (II), mosaic (III) 
рование». Но в любом случае это была немалая площадь, которая затрагивала все незанятые участки городской территории, в том числе и травянистые склоны террас Укека.

Источники сырья. Необходимость поиска исходных мест сырья для производства строительного материала очень важна, особенно когда рассматриваются вопросы реконструкции экономического базиса Золотой Орды, ключевого элемента общественно-экономической формации. Доступность и качество сырья, на примере керамического производства, во многом определяли будущее развития региона, процесса концентрации производительных сил и средств производства. Предъявляемые требования к качеству глины для производства гончарной посуды, несомненно, выше, чем для кирпича. Однако в большинстве случаев, как показывают последние исследования, красножгущая глина являлась общим исходным сырьём как для гончарного, так и для кирпичного производства. Различие происходило на этапе подготовки керамического теста. В первом случае глина отмучивалась, очищалась от крупных частиц и фракций, затем в тесто добавлялись различные присадки, которые оказывали влияние на весь последующий технологический процесс, на конечный результат. С производством кирпича было проще: вначале происходила процедура механической очистки исходного сырья от комков и крупных фракций, затем в состав теста добавлялся бой керамики, песка, органики (Сингатулин, 2017, с. 65-68). Добавки (наполнители) формируют пористость, снижают плотность и прочность кирпича, но одновременно повышают его теплотехнические характеристики. В то же время основной состав керамического теста останется идентичен составу исходного сырья. Расхождения возможны по отдельным образцам, но в целом, при наличии большой статистики, происхождение кирпича или гончарного изделия будет отождествляться с исходным местом сырья. Для более точной верификации образцов необходимо иметь распределённую базу данных по составу сырья из различных мест. В этом смысле золотоордынскому Укеку повезло. В округе имелось значительное число открытых залежей с качественной глиной (Баллод, 1923): это берега речки Назаровки (Увековки), поныне действующий глиняный карьер в северо-западной части вершины Увек и залежи многослойной глины в районе нижних террас. Частично проблема мест исходного сырья для производства керамической продукции была решена при проведении камеральных работ в 2008-2014 гг., когда исследовалась гончарная продукция из золотоордынских поселений Волго-Уральского региона (Сингатулин, 2016б, с. 105-106). В исследованиях, кроме фрагментов гончарного производства, использовались сборы кирпичной продукции из Увекского городища. Дефиниция элементного состава исследуемых образцов осуществлялась методами ВИМС и Оже-спектроскопии (Шульман, Фридрихов, 1977; Карлосон, 1981; Paparazzo, 2006) с местами предполагаемой добычи сырья. Алгоритм обработки данных построен на основе отожествления атрибутивных признаков исследуемых материалов с эталонными образцами, которые формируют профиль для керамического материала (Рaparazzo, 2001). Итогом проведённых исследований явилось отожествление маркерных керамических образцов с глиной из мест её добычи из районов к востоку от вершины Увек и устья речки Назаровки (Увековки). Эталоны элементного состава для идентификации строительного материала и гончарной продукции из Увекского городища по результатам 17 замеров исследуемых образцов представлены на рисунках 5, 6, 7.

Теплофизические и прочностные характеристики. Знание теплофизических и прочностных характеристик кирпича позволяет не только более точно характеризовать эффективность древних строительных технологий, воссоздавать, реконструировать различные сооружения (данные о несущей способности кирпича позволяют определить предел прочности строительного материала от высоты кирпичных стен и др.), но и использовать полученные данные при диагностике и для прогноза современного состояния историкоархитектурных сооружений, а также в реставрации, при использовании замещающих (искусственно воссозданных) конструктивных строительных материалов и сооружения в целом.

В процессе камеральных исследований золотоордынского кирпича в 2016-2020 гг. (Сингатулин, 2017, с. 65-68) были установлены средняя плотность кирпича, его группа по теплотехническим характеристикам, водопоглощение по массе, пределы прочности при сжатии и изгибе, определена марка кирпича в соответствии с регламентируемыми параметрами действующего ГОСТ 530-2012 «Кирпич и камень керамические» (ГОСТ, 2013) с использованием современных методов исследования строительных материалов 


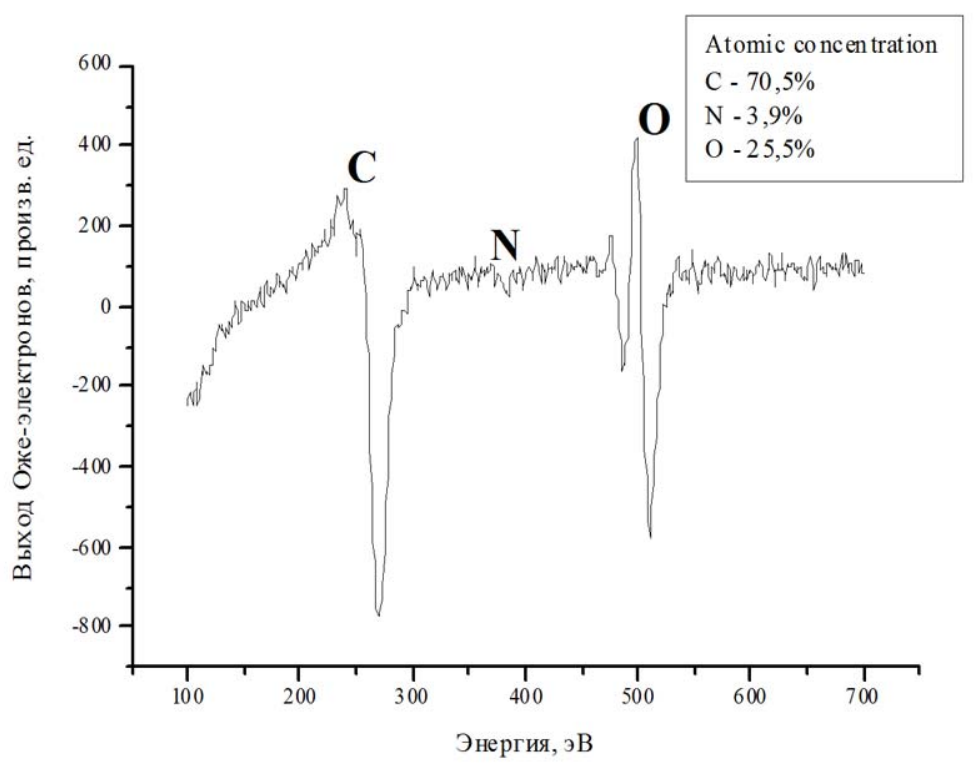

Рис. 5. Оже-спектр. Профиль 1а. Нижние террасы. Увекское городище.

Fig. 5. Auger spectrum. Profile 1a. The lower terraces. Uvek settlement.
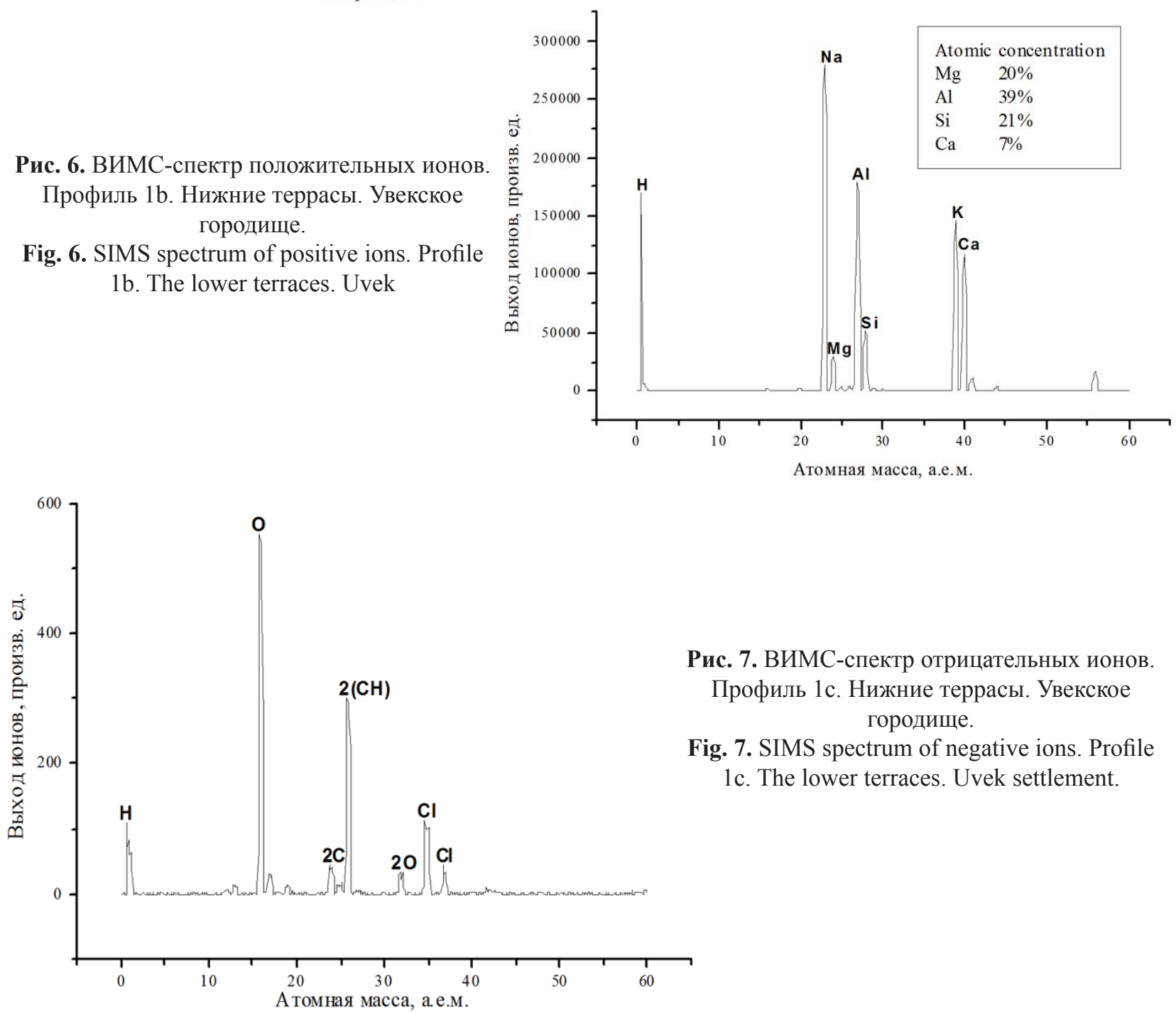

Рис. 7. ВИМС-спектр отрицательных ионов. Профиль 1с. Нижние террасы. Увекское городище.

Fig. 7. SIMS spectrum of negative ions. Profile 1c. The lower terraces. Uvek settlement.

(Брагов, Ломунов, 1995, с. 127-137). Подробное изложение методики исследований по определению прочностных и теплофизических характеристик золотоордынской плинфы можно найти в журнале «Современные наукоёмкие технологии» (Сингатулин, 2017, с. 65-68). Здесь по тексту и ниже приводятся обобщённые результаты исследований, отражающие реальное состояние проблемы.

Внутренняя структура исследованных материалов не является однородной и в большинстве случаев содержит включения в виде боя керамики, песок и органические включения, которые снижают среднюю плотность 
Таблица 2. Теплофизические и прочностные характеристики кирпича с Увекского городища Table 2 Thermophysical and Strength Characteristics of Bricks from Uvek Settlement

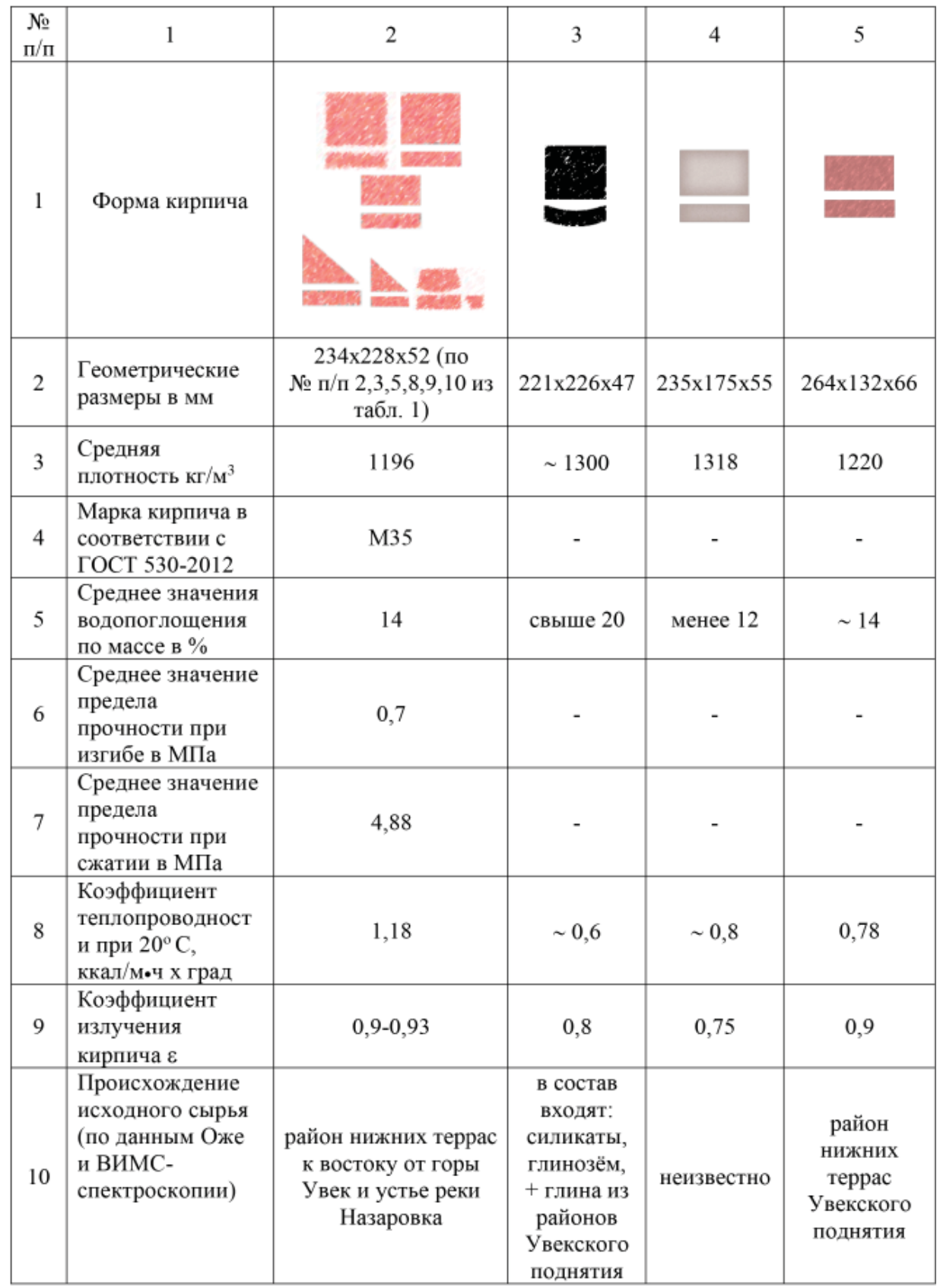

кирпича. Средняя плотность квадратного по

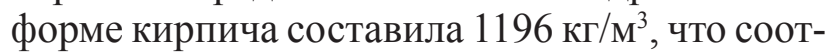
ветствует классу средней плотности изделия 1,2. Полученные данные по теплотехническим характеристикам относят исследуемый материал к эффективным. Коэффициент излучения кирпича составляет 0,9-0,93. Среднее значение водопоглощения по массе составило $14 \%$, что соответствует современным требованиям, предъявляемым для неклинкерного керамического кирпича. Определение пределов прочности при изгибе проводилось на гидравлическом прессе ПМ-20МГ4 со скоростью нагружения 0,2 MПа/с (Сингатулин, 2017 , с. 68$)$. Определение пределов прочно- сти при сжатии проводилось на гидравлическом прессе ПМГ-100МГ4 (Сингатулин, 2017, c. 68). Согласно результатам испытаний по определению пределов прочности при изгибе и сжатии, исследуемые образцы в основном соответствуют марке М35 для современного керамического кирпича. Соответствие марки M35 для золотоордынского кирпича означает, что исследуемый материал способен выдержать нагрузку, равную 35 кг на квадратный сантиметр. При линейных размерах кирпича квадратной формы $221 \times 220$ мм его несущая площадь составляет 486,2 см², статическая нагрузка при этом может достигать величины в 17017 кг. Учитывая то обстоятельство, 
что прочностные испытания производились с кирпичным строительным материалом (без предварительного отбора) возрастом не менее 660 лет, который продолжительное время находился во влажной, неблагоприятной щелочной среде, можно предполагать, что реальная прочность кирпича на момент его изготовления значительно превышала полученный в настоящее время порог прочности.

\section{Заключение}

Актуализация исследований по золотоордынскому кирпичу с помощью современных естественно-научных технологий с целью дефиниции физико-химических характеристик, форм, размеров, определения элементного состава, идентификации мест исходного сырья, производства и пр. во многом способствует разрешению проблем, связанных с особенностями средневековых технологий, процессом концентрации производительных сил и средств производства, достоверной реконструкции экономического базиса отдельных городов, регионов и золотоордынского государства в целом.

\section{ЛИТЕРАТУРА}

Баллод Ф.В. Приволжские «Помпеи». М.; Пг.: Мосполиграф, 1923.

Брагов А.М., Ломунов А.К. Использование метода Кольского для динамических испытаний конструкционных материалов // Прикладные проблемы прочности и пластичности. 1995. № 51. С. 127-137.

Браташова C.A. Увешенская станица и Саратау: к вопросу о сохранении урбосистемы Укек - Яйлак // Историко-археологические памятники Золотой Орды на территории Саратовского Поволжья. Укек: прошлое, настоящее, будущее. Мат. межд. науч.-практ. конф. / Ред. Аблязов К. А., Кульпин-Губайдуллин Э. С., Рашитов Ф. А. Саратов: Научная кинга, 2016. С. 211-218.

Васильев Д.В. О размерах золотоордынских кирпичей (Опыт статистико-метрологического анализа) // Перекрестки истории. Актуальные проблемы исторической науки. Мат. Всеросс. науч. конф. Астрахань : ИД «Астраханский университет», 2004.С. 72-79.

ГОСТ 530-2012. Кирпич и камень керамические. Общие технические условия. Взамен ГОСТ 530-2007; Введ. с 2013.07.01. М.: Стандартинформ, 2013. 39 с.

Губанов И.А., Крылова И.А., Тихонова В.Л. Дикорастущие полезные растения СССР. М.: Мысль, 1976. $360 \mathrm{c}$.

Дунаева Г.В., Рогозин И.С. Оползни Саратовского Поволжья. М.: АН СССР, 1962. 163 с.

Зиливинская Э.Д. Культовая архитектура Золотой Орды: происхождение и традиции // Поволжская археология. 2016. № 2(16). С. 44-67.

Ёлшин Д. Д. Новые исследования древнерусской плинфы: итоги и перспективы // Проблеми давньоруської та середньовічної археології / Археологія і давня історія України. Вип. 1. / Отв. ред. Г. Ю. Ивакин. Київ: Інститут археології НАН України, 2010. С. 395-407.

Карлосон Т.А. Фотоэлектронная и Оже-спектроскопия. Л.: Машиностроение, 1981. 431 с.

Краснопевиев Б.В. Фотограмметрия. М.: УПП "Репрография" МИИГАиК, 2008. 160 с.

Кротков А.А. Раскопки на Увеке в 1913 году // ТСУАК. Саратов, 1915. Вып. 32. С. 111-133.

Кульпин Э.С. Цивилизационный феномен Золотой Орды // Общественные науки и современность. 2001. № 3. C. 74-88.

Отчет Императорской Архивной Комиссии за 1891 г. / Архив ИИМК РАН, 1891. Ф. 1. Д. 30.

Сингатулин Р.А. Археологические исследования на Увекском городище в 2004 г. // Археологическое наследие Саратовского края. Вып. 7 / Отв. ред. А.И. Юдин. Саратов, Научная книга, 2006. С. 76-90.

Сингатулин Р. А. Охранно-спасательные работы на территории Увекского городища в 2005 г. // Археологическое наследие Саратовского края. Вып. 8 / Отв. ред. А. И. Юдин. Саратов, Научная книга, 2008. C. 139-155.

Сингатулин Р. А. История первых фотограмметрических исследований на Увекском городище в 1913 г. // Исторические, философские, политические и юридические науки, культурология и искусствоведение. Вопросы теории и практики. 2014. № 9(47) Ч. 1. С. 149-151.

Сингатулин Р.А. Особенности применения стереофотограмметрического мультиспектрального мониторинга в полевых археологических исследованиях // Известия высших учебных заведений. Геодезия и аэрофотосъемка. 2016а. № 2. С. 90-93.

Сингатулин Р.А. Идентификация золотоордынской керамики методами Оже и вторичной ионной масс-спектрометрии // Международный научно-исследовательский журнал. 2016б. № 7-1(49). C. $105-107$. 
Сингатулин Р.А. Теплотехнические и прочностные характеристики плинфы с Увекского городища // Современные наукоёмкие технологии. 2017. № 8. С. 65-68.

Федоров-Давыдов Г.А. Статистические методы в археологии: Учебное пособие для вузов по спец. «История». М.: Высшая школа, 1987. 216 с.

Федоров-Давыдов Г.А. Золотоордынские города Поволжья. М.: Изд-во МГУ, 1994. 232 с.

Шульман А.Р., Фридрихов С.А. Вторично-эмиссионные методы исследования твёрдого тела. М.: Наука, 1977. 552 с.

Paparazzo, E. Comment on AES and SAM microanalysis of structure ceramics by thinning and coating the backside. Yu and Jin // Surface and Interface Analysis. 2001. №31 (12). P. 1110-1111. DOI:10.1002/sia.1144.

Paparazzo, E. Recovering the past from surfaces and interfaces: experimental and cultural issues // Surface and Interface Analysis. 2006. №38. P. 357-363. DOI:10.1002/sia.2142.

\section{Информация об авторе:}

Сингатулин Рустам Адыгамович, кандидат исторических наук, доцент, заведующий лабораторией, Саратовский государственный университет имени Н.Г. Чернышевского (г. Саратов, Россия); labsgu@mail.ru

\section{REFERENCES}

Ballod, F. V. 1923. Privolzhskie "Pompei" (The Volga "Pompeii"). Moscow; Petrograd.: "Mospoligraf" Publ. (in Russian).

Bragov, A. M., Lomunov, A. K. 1995. In Prikladnye problemy prochnosti i plastichnosti (The Applied Problems of Strength and Plasticity) 51, 127-137 (in Russian).

Bratashova, S. A. 2016. In Ablyazov, K. A., Kulrin-Gubaidullin, E. A., Rashitov, F. A. (eds.). Istorikoarkheologicheskie pamiatniki Zolotoi Ordy na territorii Saratovskogo Povolzh'ia. Ukek: proshloe, nastoiashhee, budushchee (Historical and Archaeological Monuments of the Golden Horde in the Territory of Saratov Volga Region. Ukek: Past, Present, Future). Saratov: "Nauchnaia kniga" Publ., 211-218 (in Russian).

Vasil'ev, D. V. 2004. In Perekrestki istorii. Aktual'nye problemy istoricheskoy nauki (On the Crossroads of History. Current Issues of Historical Science). Astrakhan: Astrakhan State University, 72-79 (in Russian).

2013. GOST 530-2012. Kirpich i kamen' keramicheskie. Obshchie tekhnicheskie usloviia (GOST 530-2012. Ceramic Brick and Stone. General Specifications). Moscow: "Standartinform" Publ. (in Russian).

Gubanov, I. A., Krylova, I. A., Tikhonova, V. L. 1976. Dikorastushchie poleznye rasteniia SSSR (Wild Useful Plants of the USSR). Moscow: "Mysl"” Publ. (in Russian).

Dunaeva, G. V., Rogozin, I. S. 1962. In Opolzni Saratovskogo Povolzh'ia (Landslides of Saratov Volga Region). Moscow: Academy of Sciences of the USSR (in Russian).

Zilivinskaia, E. D. 2016. In Povolzhskaya arkheologiya (Volga River Region Archaeology) 16 (2), 44-67 (in Russian).

Yelshin, D. D. 2010. In Ivakin, G. Yu. (ed.). Arkheologiia i davnia istoriia Ukraïni (Archaeology and Ancient History of Ukraine) 1. Kiev: Institute of Archaeology of the National Academy of Sciences of Ukraine, 395-407 (in Russian).

Karloson, T. A. 1981. In Fotoelektronnaia i Ozhe-spektroskopiia (Photoelectron and Auger Spectroscopy) Leningrad: "Mashinostroenie" Publ. (in Russian).

Krasnopevtsev, B. V. 2008. In Fotogrammetriia (Photogrammetry). Moscow: "Reprografiia" Publ. (in Russian).

Krotkov, A. A. 1915. In Trudy Saratovsko uchenoi arhivnoi komissii (Proceedings of the Saratov Scientific Archive Commission). 32. Saratov, 111-130 (in Russian).

Kulpin, E. S. 2001. In Obshchestvennye nauki i sovremennost (Social Sciences and Contemporaneity) 3, 74-88 (in Russian).

Otchet Imperatorskoi Arkhivnoi Komissii za 1891 g. (Report by the Imperial Archival Commission for 1891) Archive of the Institute for the History of Material Culture, Russian Academy of Sciences. F. 10, dossier 30 (in Russian).

Singatulin, R. A. 2006. In Yudin, A. I. (ed.). Arkheologicheskoe nasledie Saratovskogo kraia. (The Archaeological Heritage of the Saratov Region) 7. Saratov: "Nauchnaia kniga" Publ., 76-90 (in Russian).

Singatulin, R. A. 2008. In Yudin, A. I. (ed.). Arkheologicheskoe nasledie Saratovskogo kraia. (The Archaeological Heritage of the Saratov Region) 8. Saratov: "Nauchnaia kniga" Publ., 139-155. (in Russian). 
Singatulin, R. A. 2014. In Istoricheskiye, filosofskiye, politicheskiye i yuridicheskiye nauki, kul'turologiya $i$ iskusstvovedeniye. Voprosy teorii $i$ praktiki (Historical, philosophical and law sciences and study of art. Theory and practice issues) 47 (9) part 1. 149-151 (in Russian).

Singatulin, R. A. 2016. In Izvestiia vysshikh uchebnykh zavedenii. Geodeziia i aehrofotos"emka (Proceedings of Higher Educational Institutions. Geodesy and Aerial Photography) 2. 90-93 (in Russian).

Singatulin, R. A. 2016. In Mezhdunarodnyi nauchno-issledovatel'skii zhurnal (International Research Journal) 7(49), part 1. 105-107 (in Russian).

Singatulin, R. A. 2017. In Sovremennye naukoemkie tekhnologii (Modern High Technology) 8. 65-68 (in Russian).

Fedorov-Davydov, G. A. 1987. Statisticheskie metody v arkheologii: Uchebnoe posobie dlia vuzov po spets. "Istoriia» (Statistical Methods in Archaeology: Study Guide for Universities with Specialization in History). Moscow: "Vysshaia shkola" Publ. (in Russian).

Fedorov-Davydov, G. A. 1994. Zolotoordynskie goroda Povolzh'ia (Golden Horde Towns in the Volga Area). Moscow: Moscow State University (in Russian).

Schulman, A. R., Fridrikhov, S. A. 1977. Vtorichno-ehmissionnye metody issledovaniya tvyordogo tela (Secondary Emission Methods for Solid State Research). Moscow: "Nauka" Publ. (in Russian).

Paparazzo, E. 2001. In. Surface and Interface Analysis 31(12). 1110-1111. DOI:10.1002/sia.1144 (in English).

Paparazzo, E. 2006. In Surface and Interface Analysis (38). 357-363. DOI:10.1002/sia.2142 (in English).

\section{About the Author:}

Singatulin Rustam A. Candidate of Historical Sciences, Associate Professor, Head of Laboratory. Saratov State University named after N.G. Chernyshevsky. Astrakhan Str., 83, Saratov, 410012, Russian Federation; labsgu@mail.ru 